\title{
REFLEKSI PAHAM JABARIYAH DAN QADARIYAH
}

\section{Sidik}

\author{
IAIN Palu, Fakultas Ushuluddin Adab dab Dakwah
}

\begin{abstract}
Both of these flow (Jabariyah and Qadarites), has a different ideology against human freedom though equally based on the proposition of the Qur'an, but there is a meeting point between the flow Jabariyah and Qadarites that humans actually have free will and therefore he will be held responsibility for the decision, though the decision is basically a fulfillment of destiny (provision) that have been determined. In other words, human free will cannot be achieved without the intervention of Allah SWT. In addition, Jabariyah teaching actually based on strong faith in Allah SWT Iradat qudrat and, coupled with the nature of His wahdaniat. For Qadarites man is the perpetrator goodness and evil, faith and kufr. This flow includes Jabariyah its reasons and arguments and opinions so that with a view to avoid the mistakes that plunged into error adherents of religion and the glory and holiness of Allah SWT
\end{abstract}

\section{Keywords: Reflection, Jabariyah, Qadariyah}

Kedua aliran ini (Jabariyah dan Qadariyah), memiliki paham yang berbeda terhadap kebebasan manusia meskipun sama-sama berlandaskan dalil al-Qur'an, namun terdapat titik temu antara keduanya bahwa manusia benar-benar memiliki kebebasan berkehendak dan karenanya ia akan dimintai pertanggungjawaban atas keputusannya, meskipun demikian keputusan tersebut pada dasarnya 
merupakan pemenuhan takdir yang telah ditentukan. Dengan kata lain, kebebasan berkehendak manusia tidak dapat tercapai tanpa campur tangan Allah swt. Di samping itu paham Jabariyah sebenarnya didasarkan karena kuatnya iman terhadap qudrat dan iradat Allah swt. Bagi Qadariyah manusia adalah pelaku kebaikan dan keburukan, keimanan dan juga kekufuran. Kedua aliran ini mengemukakan alasan dan dalil serta pendapat yang demikian itu dengan maksud untuk menghindarkan diri dari kekeliruan yang menjerumuskan penganutnya ke dalam kesesatan beragama untuk mencapai kemuliaan dan kesucian Allah swt.

\section{Kata Kunci: Refleksi, Jabariyah, Qadariyah}

\section{PENDAHULUAN}

Sejak rasulullah saw diutus kepada umat Islam turunnya wahyu Allah dan keluarnya ungkapan serta tervisualisasikannya perilaku dan keadaan hidup rasulullah saw lahirlah sebuah disiplin Ilmu yang para orientalis menyebutnya "teologi" yakni cabang ilmu yang mempelajari segala sesuatu yang berkaitan dengan keyakinan beragama dan semua hal yang berhubungan dengan Tuhan. ${ }^{1}$ Dikalangan umat Islam sejak awal telah terjadi perbedaaan pendapat mengenai teologi baik dalam bentuk praktis maupun teoritis. Perbedaan tersebut tampak melalui perdebatan dalam masalah kalam yang ahirnya menimbulkan berbagai aliran-aliran dalam Islam. Dalam perdebatan tentang teologi ini, yang diperdebatkan bukanlah akidah-akidah pokok seperti iman kepada Allah, kepada malaikat dan lain sebagainya, melainkan perdebatan masalah akidah cabang yang membahas bagaimana sifat Allah, Al-Qur'an itu baru (jadid) ataukah

\footnotetext{
${ }^{1}$ Teologi, http://id.wikipedia.org/wiki/Teologi (diakses tanggal 9 Oktober 2014)
} 
Sidik, Refleksi Paham Jabariyah dan Qadariyah... 275

azali (qadim), malaikat itu termasuk golongan jin atau bukan, dan hal-hal yang berkaitan dengan itu.

Pebedaan tersebut ahirnya menimbulkan berbagai macam aliran diantaranya seperti Khawarij, Syiah, Murji'ah, Mu'tazilah, Jabariyah dan Qodariyah, Asy'ariyah dan Maturidiyah. Dalam tulisan in penulis hanya akan mengulas Refleksi Paham Jabariyah dan Qadariyah dari berbagai argumen yang dikemukakan oleh para tokoh atau penganut masing-masing dari aliran yang dimaksud

\section{PAHAM JABARIYAH}

Secara bahasa Jabariyah berasal dari bahasa arab "jabara" artinya memaksa. Di dalam kamus Munjid dijelaskan bahwa nama

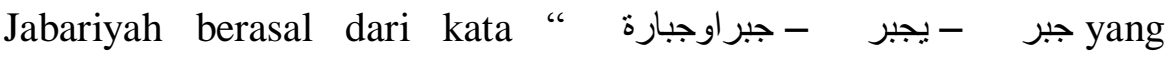
mengandung pengertian "memaksa" atau "mengharuskan dalam kalimat misalnya اكرهه و الزمه بفعله "dia memaksakannya dan mewajibkan melakukan hal itu. ${ }^{2}$ Salah satu sifat dari Allah adalah alJabbar yang berarti Allah Maha Memaksa. Sedangkan secara istilah Jabariyah adalah menolak adanya perbuatan dari manusia dan menyandarkan semua perbuatan kepada Allah. Dengan kata lain adalah manusia mengerjakan perbuatan dalam keadaan terpaksa (majbur).

Jaham bin Sofyan berpendapat mengenai aliran Jabariyah "manusia tidak mempunyai kodrat untuk berbuat sesuatu dan tidak mempunyai kesanggupan dia hanya terpaksa dalam semua perbuatannya" dia tidak mempunyai kodrat dan ikhtiar, melainkan Tuhanlah yang menciptakan perbuatan-perbuatan pada dirinya seperti ciptaan-ciptaan Tuhan pada benda mati, memang perbuatanperbuatan itu dinisbatkan kepada orang tersebut tetapi itu hanyalah

${ }^{2}$ Al-Munjid fi al-Lugati wal al- 'A 'lam, (Beirut: Dar al-Masriq, 2011, Cet. ke - 44) 78 
nisbah majazi, Jaham juga berkata apabila paksaan itu telah tetap maka taklif adalah paksaan juga. ${ }^{3}$

Dalam tulisannya Harun Nasution menjelaskan bahwa Jabariyah adalah paham yang meyakini bahwa segala perbuatan manusia telah ditentukan dari semula oleh Qadha dan Qadar Allah. Manusia dalam paham ini terikat pada kehendak mutlak Tuhan. ${ }^{4}$ Maksudnya adalah bahwa setiap perbuatan yang dikerjakan manusia tidak berdasarkan kehendak manusia, tapi diciptakan oleh Tuhan dan dengan kehendak-Nya, di sini manusia tidak mempunyai kebebasan dalam berbuat, karena tidak memiliki kemampuan. Ada yang mengistilahlkan bahwa Jabariyah adalah aliran manusia menjadi wayang dan Tuhan sebagai dalangnya. ${ }^{5}$

Ada beberapa pendapat yang melatar belakangi lahirnya aliran Jabariyah. Abu Zahra menuturkan bahwa paham ini muncul sejak zaman sahabat dan masa Bani Umayyah. Ketika itu para ulama membicarakan tentang masalah Qadar dan kekuasaan manusia ketika berhadapan dengan kekuasaan mutlak Tuhan. Adapaun tokoh yang mendirikan aliran ini menurut Abu Zahrah dan al-Qasimi adalah Jahm bin Safwan yang bersamaan dengan munculnya aliran Qadariayah. ${ }^{6}$

Pendapat yang lain mengatakan bahwa paham jabariyah ini diduga telah muncul sejak sebelum agama Islam datang ke masyarakat Arab. Kehidupan bangsa Arab yang diliputi oleh gurun pasir sahara telah memberikan pengaruh besar dalam cara hidup

\footnotetext{
${ }^{3}$ Asy-Syahrastani, Al-Milal wa An-Nihal, Dar al- Fikri, Beirut, 1985, 87

${ }^{4}$ Harun Nasution, Teologi Islam: Aliran-aliran Sejarah Analisa Perbandingan, (Jakarta:UI-Press, 1986), 31.

${ }^{5}$ Harun Nasution, ${ }^{3} 4$.

${ }^{6}$ Tim, Ensiklopedi Islam, “Jabariyah” Cet. IV, Jakarta: Ikkhtiar Baru
} 
mereka. Di tengah bumi yang disinari terik matahari dengan air yang sangat sedikit dan udara yang panas ternyata tidak dapat memberikan kesempatan bagi tumbuhnya pepohonan dan suburnya tanaman, tapi yang tumbuh hanya rumput yang kering dan beberapa pohon kuat untuk menghadapi panasnya musim serta keringnya udara.

Harun Nasution menjelaskan bahwa dalam situasi demikian masyarakat arab tidak melihat jalan untuk mengubah keadaan disekeliling mereka sesuai dengan kehidupan yang diinginkan. Mereka merasa lemah dalam menghadapi kesukaran-kesukaran hidup. Artinya mereka banyak tergantung dengan Alam, sehingga menyebabakan mereka kepada paham fatalism. ${ }^{7}$

Terlepas dari perbedaan pendapat tentang awal lahirnya aliran ini, dalam Alquran sendiri banyak terdapat ayat-ayat yeng menunjukkan tentang latar belakang lahirnya paham Jabariyah, diantaranya:

a. Q.S ash-Shaffat: 96

$$
\text { وَالسَّهُ خَلَكَكُمْ وَمَا تَعْمَلُونْ }
$$

Artinya: "Padahal Allah-lah yang menciptakan kamu dan apa yang kamu perbuat itu".

b. QS al-Anfal: 17

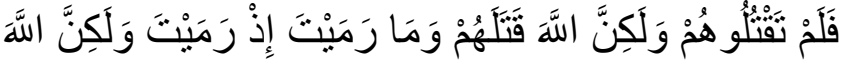

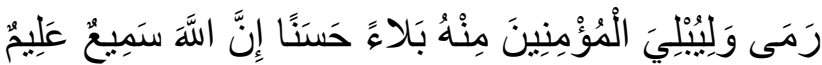

c. Artinya: "Maka (yang sebenarnya) bukan kamu yang membunuh mereka, akan tetapi Allahlah yang membunuh mereka, dan bukan kamu yang melempar ketika kamu melempar, tetapi Allah-lah yang melempar. (Allah berbuat demikian untuk membinasakan mereka) dan untuk memberi

\footnotetext{
$7 \mathrm{H}$ arun Nasution, 32.

${ }^{8}$ Agus Hidayatullah, dkk. Al-Jamil, Al-Qur'an Tajwid dan terjemah, ${ }^{(B}$ ekasi: ${ }^{C}$ ipta Bagus Segara' ${ }^{2012)}, 449$.
} 
kemenangan kepada orang-orang mukmin, dengan kemenangan yang baik. Sesungguhnya Allah Maha mendengar lagi Maha mengetahui." 9

d. Q.S al-Insan: 30

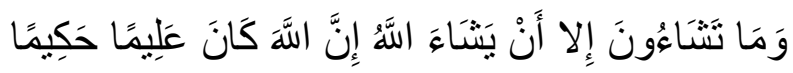

Artinya : "Dan kamu tidak mampu (menempuh jalan itu), kecuali bila dikehendaki Allah. Sesungguhnya Allah adalah Maha mengetahui lagi Maha Bijaksana."

Selain ayat-ayat Alquran di atas benih-benih paham al-Jabar juga dapat dilihat dalam beberapa peristiwa sejarah:

a. Suatu ketika Nabi menjumpai sahabatnya yang sedang bertengkar dalam masalah Takdir Tuhan, Nabi melarang mereka untuk memperdebatkan persoalan tersebut, agar terhindar dari kekeliruan penafsiran tentang ayat-ayat Tuhan mengenai takdir.

b. Khalifah Umar bin al-Khaththab pernah menangkap seorang pencuri. Ketika diinterogasi, pencuri itu berkata "Tuhan telah menentukan aku mencuri". Mendengar itu Umar kemudian marah sekali dan menganggap orang itu telah berdusta. Oleh karena itu Umar memberikan dua jenis hukuman kepada orang itu, yaitu: hukuman potongan tangan karena mencuri dan hukuman dera karena menggunakan dalil takdir Tuhan.

c. Ketika Khalifah Ali bin Abu Thalib ditanya tentang qadar Tuhan dalam kaitannya dengan siksa dan pahala. Orang tua itu bertanya,"apabila perjalanan (menuju perang siffin) itu terjadi dengan qadha dan qadar Tuhan, tidak ada pahala sebagai balasannya. Kemudian Ali menjelaskannya bahwa Qadha dan

\footnotetext{
${ }^{9}$ Agus Hidayatullah, dkk. Al-Jamil, Al-Qur'an Tajwid dan terjemah, 179.
} 
Sidik, Refleksi Paham Jabariyah dan Qadariyah... 279

Qadha Tuhan bukanlah sebuah paksaan. Pahala dan siksa akan didapat berdasarkan atas amal perbuatan manusia. Kalau itu sebuah paksaan, maka tidak ada pahala dan siksa, gugur pula janji dan ancaman Allah, dan tidak ada pujian bagi orang yang baik dan tidak ada celaan bagi orang berbuat dosa.

d. Adanya paham Jabar telah mengemuka kepermukaan pada masa Bani Umayyah yang tumbuh berkembang di Syiria.

Di samping adanya bibit pengaruh paham jabar yang telah muncul dari pemahaman terhadap ajaran Islam itu sendiri. Ada sebuah pandangan mengatakan bahwa aliran Jabar muncul karena adanya pengaruh dari pemikriran asing, yaitu pengaruh agama Yahudi bermazhab Qurra dan agama Kristen bermazhab Yacobit.

Dengan demikian, latar belakang lahirnya aliran Jabariyah dapat dibedakan kedalam dua faktor, yaitu faktor yang berasal dari pemahaman ajaran-ajaran Islam yang bersumber dari Alquran dan Sunnah, yang mempunyai paham yang mengarah kepada Jabariyah. Lebih dari itu adalah adanya pengaruh dari luar Islam yang ikut andil dalam melahirkan aliran ini.

Adapun yang menjadi dasar munculnya paham ini adalah sebagai reaksi dari tiga perkara: pertama, adanya paham Qadariyah, keduanya, terlalu tekstualnya pamahaman agama tanpa adanya keberanian menakwilkan dan ketiga adalah adanya aliran salaf yang ditokohi Muqatil bin Sulaiman yang berlebihan dalam menetapkan sifat-sifat Tuhan sehingga membawa kepada Tasybih.

Ajaran-ajaran Jabariyah dapat dibedakan menjadi dua kelompok, yaitu Jabariyah Ekstrim dan Jabariyah Moderat. Pertama, aliran ekstrim. Di antara tokoh adalah Jahm bin Shofwan dengan pendapatnya adalah bahwa manusia tidak mempu untuk berbuat apaapa. Ia tidak mempunyai daya, tidak mempunyai kehendak sendiri, dan tidak mempunyai pilihan. Pendapat Jahm tentang keterpaksaan 
ini lebih dikenal dibandingkan dengan pendapatnya tentang surga dan neraka, konsep iman, kalam Tuhan, meniadakan sifat Tuhan, dan melihat Tuhan di akherat. Surga dan neraka tidak kekal, dan yang kekal hanya Allah. Sedangkan iman dalam pengertianya adalah ma'rifat atau membenarkan dengan hati, dan hal ini sama dengan konsep yang dikemukakan oleh kaum Murjiah. Kalam Tuhan adalah makhluk. Allah tidak mempunyai keserupaan dengan manusia seperti berbicara, mendengar, dan melihat, dan Tuhan juga tidak dapat dilihat dengan indera mata di akherat kelak. Aliran ini dikenal juga dengan nama al-Jahmiyyah atau Jabariyah Khalisah.

Ja'ad bin Dirham, menjelaskan tentang ajaran pokok dari Jabariyah adalah Alquran adalah makhluk dan sesuatu yang baru dan tidak dapat disifatkan kepada Allah. Allah tidak mempunyai sifat yang serupa dengan makhluk, seperti berbicara, melihat dan mendengar. Manusia terpaksa oleh Allah dalam segala hal.

Dengan demikian ajaran Jabariyah yang ekstrim mengatakan bahwa manusia lemah, tidak berdaya, terikat dengan kekuasaan dan kehendak Tuhan, tidak mempunyai kehendak dan kemauan bebas sebagaimana dimilki oleh paham Qadariyah. Seluruh tindakan dan perbuatan manusia tidak boleh lepas dari skenario dan kehendak Allah. Segala akibat, baik dan buruk yang diterima oleh manusia dalam perjalanan hidupnya adalah merupakan ketentuan Allah.

Kedua, ajaran Jabariyah yang moderat adalah Tuhan menciptakan perbuatan manusia, baik itu positif atau negatif, tetapi manusia mempunyai bagian di dalamnya. Tenaga yang diciptakan dalam diri manusia mempunyai efek untuk mewujudkan perbuatannya. Manusia juga tidak dipaksa, tidak seperti wayang yang dikendalikan oleh dalang dan tidak pula menjadi pencipta perbuatan, tetapi manusia memperoleh perbuatan yang diciptakan tuhan. Tokoh yang berpaham seperti ini adalah Husain bin Muhammad an-Najjar yang mengatakan bahwa Tuhan menciptakan segala perbuatan manusia, tetapi manusia mengambil bagian atau peran dalam 
Sidik, Refleksi Paham Jabariyah dan Qadariyah... |281

mewujudkan perbuatan-perbuatan itu dan Tuhan tidak dapat dilihat di akherat. Sedangkan adh-Dhirar (tokoh jabariayah moderat lainnya) pendapat bahwa Tuhan dapat saja dilihat dengan indera keenam dan perbuatan dapat ditimbulkan oleh dua pihak.

\section{PAHAM QADARIYAH}

Secara etimologis, Qadariyah berasal dari bahasa Arab, yaitu qadara " قدر - يقر yang bemakna kemampuan dan kekuatan. ${ }^{10}$ Adapun secara terminologi istilah adalah suatu aliran yang percaya bahwa segala tindakan manusia tidak diintervensi oleh Allah. Aliranaliran ini berpendapat bahwa tiap-tiap orang adalah pencipta bagi segala perbuatannya, ia dapat berbuat sesuatu atau meninggalkannya atas kehendaknya sendiri. Aliran ini lebih menekankan atas kebebasan dan kekuatan manusia dalam mewujudkan perbutanperbutannya. Harun Nasution menulis bahwa aliran qadariayah berpendapat bahwa manusia mempunyai kekuatan, kemerdekaan dan kebebasan untuk melaksanakan kehendaknya dan menentukan perjalanan hidupnya, dan bukan berasal dari pengertian bahwa manusia terpaksa tunduk pada qadar Tuhan. Kaum orientalis menyebut paham ini sebagai free will atau free act sedangkan jabariyah disebut sebagai fatalism atau predestination. ${ }^{11}$

Menurut Ahmad Amin sebagaimana dikutip oleh Hadariansyah, orang-orang yang berpaham Qadariyah adalah mereka yang mengatakan bahwa manusia memiliki kebebasan berkehendak dan memiliki kemampuan dalam melakukan perbuatan. Manusia mampu melakukan perbuatan, mencakup semua perbuatan, yakni baik dan buruk. Sejarah lahirnya aliran Qadariyah tidak dapat diketahui secara pasti dan masih merupakan sebuah perdebatan. Akan tetepi menurut Ahmad Amin, ada sebagian pakar teologi yang $\mathrm{ke}-44)$

${ }^{10}$ Al-Munji fi al-Lugati wal al- 'A'lam, (Beirut: Dar al-Masriq, 2011, Cet.

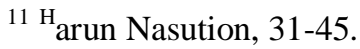


mengatakan bahwa Qadariyah pertama kali dimunculkan oleh Ma'bad al-Jauhani dan Ghilan ad-Dimasyqi sekitar tahun 70 H/689M.

Ibnu Nabatah menjelaskan dalam kitabnya, sebagaimana yang dikemukakan oleh Ahmad Amin, aliran Qadariyah pertama kali dimunculkan oleh orang Irak yang pada mulanya beragama Kristen, kemudian masuk Islam dan kembali lagi ke agama Kristen. Namanya adalah Susan, demikian juga pendapat Muhammad Ibnu Syu'ib. Sementara W. Montgomery Watt menemukan dokumen lain yang menyatakan bahwa paham Qadariyah terdapat dalam kitab ar-Risalah dan ditulis untuk Khalifah Abdul Malik oleh Hasan al-Basri sekitar tahun 700M.

Ditinjau dari segi politik kehadiran mazhab Qadariyah sebagai isyarat menentang politik Bani Umayyah, karena itu kehadiran Qadariyah dalam wilayah kekuasaanya selalu mendapat tekanan, bahkan pada zaman Abdul Malik bin Marwan pengaruh Qadariyah dapat dikatakan lenyap tapi hanya untuk sementara saja, sebab dalam perkembangan selanjutnya paham Qadariyah itu dianut oleh Mu'tazilah sedangkan paham Jabariyah walaupun tidak identik dengan paham yang dibawa oleh Ibn Safwan atau Al-Najjar dan Dirar, pengaruh aliran ini terdapat dalam al-Asy'ariah. ${ }^{12}$

Harun Nasution menjelaskan pendapat Ghalian tentang ajaran Qadariyah bahwa manusia berkuasa atas perbuatan-perbutannya. Manusia sendirilah yang melakukan perbuatan baik atas kehendak dan kekuasaan sendiri dan manusia sendiri pula yang melakukan atau menjauhi perbuatan-perbutan jahat atas kemauan dan dayanya sendiri. Tokoh an-Nazzam menyatakan bahwa manusia hidup mempunyai daya, dan dengan daya itu ia dapat berkuasa atas segala perbuatannya.

$12 \mathrm{H}_{\text {arun Nasution, } 37 .}$ 
Sidik, Refleksi Paham Jabariyah dan Qadariyah... $\mid 283$

Dengan demikian bahwa segala tingkah laku manusia dilakukan atas kehendaknya sendiri. Manusia mempunyai kewenangan untuk melakukan segala perbuatan atas kehendaknya sendiri, baik berbuat baik maupun berbuat jahat. Oleh karena itu, ia berhak mendapatkan pahala atas kebaikan yang dilakukannya dan juga berhak pula memperoleh hukuman atas kejahatan yang diperbuatnya. Ganjaran kebaikan di sini disamakan dengan balasan surga kelak di akherat dan ganjaran siksa dengan balasan neraka kelak di akherat, itu didasarkan atas pilihan pribadinya sendiri, bukan oleh takdir Tuhan. Karena itu sangat pantas, orang yang berbuat akan mendapatkan balasannya sesuai dengan tindakannya.

Paham takdir yang dikembangkan oleh Qadariyah berbeda dengan konsep yang umum yang dipakai oleh bangsa Arab ketika itu, yaitu paham yang mengatakan bahwa nasib manusia telah ditentukan terlebih dahulu. Dalam perbuatannya, manusia hanya bertindak menurut nasib yang telah ditentukan sejak azali terhadap dirinya. Dengan demikian takdir adalah ketentuan Allah yang diciptakan-Nya bagi alam semesta beserta seluruh isinya, sejak azali, yaitu hukum yang dalam istilah Alquran adalah sunnatullah.

Secara alamiah sesungguhnya manusia telah memiliki takdir yang tidak dapat diubah. Manusia dalam demensi fisiknya tidak dapat bebruat lain, kecuali mengikuti hukum alam. Misalnya manusia ditakdirkan oleh Tuhan tidak mempunyai sirip seperti ikan yang mampu berenang di lautan lepas. Demikian juga manusia tidak mempunyai kekuatan seperti gajah yang mampu membawa barang seratus kilogram.

Dengan pemahaman seperti ini tidak ada alasan untuk menyandarkan perbuatan kepada Allah. Di antara dalil (naqli) yang mereka gunakan adalah banyak ayat-ayat Alquran yang berbicara dan mendukung paham itu.

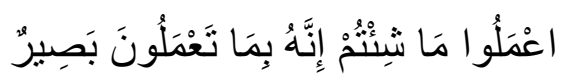


Artinya : "Kerjakanlah apa yang kamu kehendaki sesungguhnya Ia melihat apa yang kamu perbuat”. (QS. Fush-Shilat : 40).

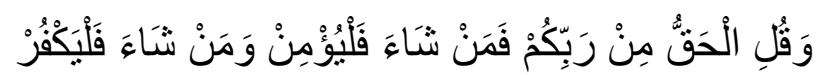

Artinya : "Katakanlah kebenaran dari Tuhanmu, barang siapa yang mau beriman maka berimanlah dan barang siapa yang mau kafir maka kafirlah". (QS. Al-Kahfi : 29).

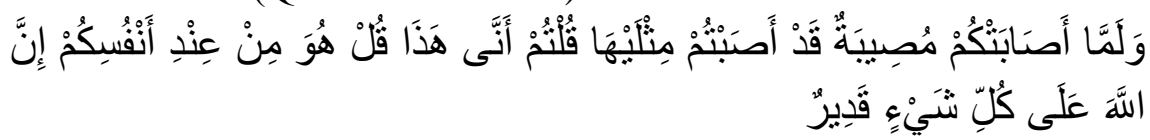

Artinya : "dan mengapa ketika kamu ditimpa musibah (pada peperangan Uhud), Padahal kamu telah menimpakan kekalahan dua kali lipat kepada musuh-musuhmu (pada peperangan Badar), kamu berkata: "Darimana datangnya (kekalahan) ini?" Katakanlah: "Itu dari (kesalahan) dirimu sendiri". Sesungguhnya Allah Maha Kuasa atas segala sesuatu". (QS.Ali Imran :165).

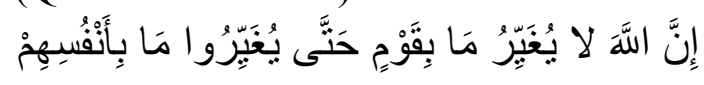

Artinya : "Sesungguhnya Allah tidak merobah Keadaan sesuatu kaum sehingga mereka merobah keadaan[Tuhan tidak akan merobah Keadaan mereka, selama mereka tidak merobah sebabsebab kemunduran mereka.] yang ada pada diri mereka sendiri”. (QS.Ar-R'd :11).

\section{REFLEKSI PAHAM QADARIYAH DAN JABARIYAH}

Sebuah Perbandingan tentang Musibah. Dalam paham Jabariyah, berkaitan dengan perbuatannya, manusia digambarkan bagai kapas yang melayang di udara yang tidak memiliki sedikit pun daya untuk menentukan gerakannya yang ditentukan dan digerakkan oleh arus angin. Sedang yang berpaham Qadariyah akan menjawab, bahwa perbuatan manusia ditentukan dan dikerjakan oleh manusia, bukan Allah. Dalam paham Qadariyah, berkaitan dengan 
Sidik, Refleksi Paham Jabariyah dan Qadariyah... 285

perbuatannya, manusia digambarkan sebagai berkuasa penuh untuk menentukan dan mengerjakan perbuatannya.

Pada perkembangan selanjutnya, paham Jabariyah disebut juga sebagai paham tradisional dan konservatif dalam Islam dan paham Qadariyah disebut juga sebagai paham rasional dan liberal dalam Islam. Kedua paham teologi Islam tersebut melandaskan diri di atas dalil-dalil naqli (agama) - sesuai pemahaman masing-masing atas nash-nash agama (Alquran dan hadits-hadits Nabi Muhammad) dan aqli (argumen pikiran). Di negeri-negeri kaum Muslimin, seperti di Indonesia, yang dominan adalah paham Jabariyah. Orang Muslim yang berpaham Qadariyah merupakan kalangan yang terbatas atau hanya sedikit dari mereka.

Kedua paham itu dapat dicermati pada suatu peristiwa yang menimpa dan berkaitan dengan perbuatan manusia, misalnya, kecelakaan pesawat terbang. Bagi yang berpaham Jabariyah biasanya dengan enteng mengatakan bahwa kecelakaan itu sudah kehendak dan perbuatan Allah. Sedang, yang berpaham Qadariyah condong mencari tahu di mana letak peranan manusia pada kecelakaan itu.

Kedua paham teologi Islam tersebut membawa efek masingmasing. Pada paham Jabariyah semangat melakukan investigasi sangat kecil, karena semua peristiwa dipandang sudah kehendak dan dilakukan oleh Allah. Sedang, pada paham Qadariyah, semangat investigasi amat besar, karena semua peristiwa yang berkaitan dengan peranan (perbuatan) manusia harus dipertanggungjawabkan oleh manusia melalui suatu investigasi.

Dengan demikian, dalam paham Qadariyah, selain manusia dinyatakan sebagai makhluk yang merdeka, juga adalah makhluk yang harus bertanggung jawab atas perbuatannya. Posisi manusia demikian tidak terdapat di dalam paham Jabariyah. Akibat dari perbedaan sikap dan posisi itu, ilmu pengetahuan lebih pasti berkembang di dalam paham Qadariyah ketimbang Jabariyah. 


\section{PENUTUP}

Bahwa titik temu antara Aliran Jabariyah dan Qadariyah adalah manusia benar-benar memiliki kebebasan berkehendak dan karenanya ia akan dimintai pertanggungjawaban atas keputusannya, meskipun demikian keputusan tersebut pada dasarnya merupakan pemenuhan takdir (ketentuan) yang telah ditentukan. Dengan kata lain, kebebasan berkehendak manusia tidak dapat tercapai tanpa campur tangan Allah swt. Misalnya seseorang dapat membuat makanan apasaja yang dikendakinya, tetapi dalam hal ini makanan itu tidak akan jadi bilamana campur tangan Tuhan atau kehendak Tuhan tidak ada, yakni bila bahan makanan yang bersumber dari tumbuh-tumbuhan atau hewan tidak ada sementara makhluk tersebut adalah ciptaan Allah swt.

Dalam masalah Iman dan Kufur ajaran Jabariyah bisa diberlakukan untuk menyampaikan dakwah Islam sehingga dapat merangkul berbagai golongan Islam yang masih memerlukan pengayoman. Di samping itu pendapat-pendapat Jabariyah sebenarnya didasarkan karena kuatnya iman terhadap qudrat dan iradat Allah swt, ditambah pula dengan sifat wahdaniat-Nya.

Bagi Qadariyah manusia adalah pelaku kebaikan dan juga keburukan, keimanan dan juga kekufuran. Aliran ini termasuk Jabariyah mengemukakan alasan-alasan dan dalil-dalil serta pendapat yang demikian itu dengan maksud untuk menghindarkan diri kekeliruan yang menjerumuskan penganutnya ke dalam kesesatan beragama dan mencapai kemuliaan dan kesucian Allah swt. dengan sesempurna mungkin.

\section{DAFTAR PUSTAKA}

Luwis Ma'luf. Al-Munjid fi al-Lugati wal al-'A'lam. Beirut: Dar al-Masriq, 1998 
Sidik, Refleksi Paham Jabariyah dan Qadariyah... 287

Asy-Syahrastani, Al-Milal wa An-Nihal, Dar al- Fikri, Beirut, 1985

Agus Hidayatullah, dkk. Al-Jamil, Al-Qur'an Tajwid dan terjemah. Bekasi: Cipta Bagus Segara, 2012

Harun Nasution. Teologi Islam: Aliran-aliran Sejarah Analisa Perbandingan. Jakarta: UI-Press, 1986

Tim, Ensiklopedi Islam, “Jabariyah” Cet. IV, Jakarta: Ikkhtiar Baru Van Hoeve, 1997

http://syafieh.blogspot.com/2013/03/aliran-teologi-islamjabariyah-dan.html

Teologi, http://id.wikipedia.org/wiki/Teologi (diakses tanggal 9 Oktober 2014) 